\title{
Fabrication of
}

\section{$\mathrm{SiO}_{\mathrm{x}}$-G/PAA-PANi/Graphene} Composite With Special Cross-Doped Conductive Hydrogels as Anode Materials for Lithium Ion Batteries

\author{
Yuanhong Liao ${ }^{1}$, Kang Liang ${ }^{1}$, Yurong Ren ${ }^{1 *}$ and Xiaobing Huang ${ }^{2}$ \\ ${ }^{1}$ School of Materials Science and Engineering, Jiangsu Collaborative Innovation Center of Photovoltaic Science and \\ Engineering, Changzhou University, Changzhou, China, ${ }^{2}$ Hunan Province Cooperative Innovation Center for the Construction \\ \& Development of Dongting Lake Ecological Economic Zone, College of Chemistry and Materials Engineering, Hunan \\ University of Arts and Science, Changde, China
}

\section{OPEN ACCESS}

Edited by:

Zhangxing He,

North China University of Science and

Technology, China

Reviewed by:

Mingyong Wang,

University of Science and Technology

Beijing, China

Xifei Li,

Xi'an University of Technology, China

*Correspondence: Yurong Ren

ryrchem@163.com

Specialty section: This article was submitted to

Electrochemistry,

a section of the journal

Frontiers in Chemistry

Received: 29 October 2019

Accepted: 31 January 2020

Published: 21 February 2020

Citation:

Liao Y, Liang K, Ren Y and Huang X (2020) Fabrication of

$\mathrm{SiO}_{\mathrm{x}}$-G/PAA-PANi/Graphene Composite With Special Cross-Doped

Conductive Hydrogels as Anode

Materials for Lithium Ion Batteries.

Front. Chem. 8:96.

doi: 10.3389/fchem.2020.00096
Silicon oxides $\left(\mathrm{SiO}_{x}\right)$ have been considered to be the likeliest material to substitute graphite anode for lithium-ion batteries (LIBS) due to its high theoretical capacity, appropriate working potential plus rich abundance. Nevertheless, the two inherent disadvantages of volume expansion and low electrical conductivity of $\mathrm{SiO}_{\mathbf{x}}$ have been a main obstacle to its application. Here, $\mathrm{SiO}_{\mathrm{x}}-\mathrm{G} / \mathrm{PAA}-\mathrm{PANi} / \mathrm{graphene}$ composite has been successfully synthesized by in-situ polymerization, in which $\mathrm{SiO}_{\mathrm{x}}-\mathrm{G}$ particles linked together by a graphene-doped polyacrylic acid-polyaniline conductive flexible hydrogel and $\mathrm{SiO}_{x}-\mathrm{G}$ is encapsulated inside the conductive hydrogel. We demonstrate that $\mathrm{SiO}_{x}$-G/PAA-PANi/graphene composite possesses a discharge-specific capacity of $842.3 \mathrm{~mA} \mathrm{~h} \mathrm{~g}^{-1}$ at a current density of $500 \mathrm{~mA} \mathrm{~g}^{-1}$ after a cycle life of 100 cycles, and a good initial coulombic efficiency (ICE) of $74.77 \%$. The superior performance probably due to the lithium ion transmission rate and the electric conductivity enhanced by the three-dimensional (3D) structured conductive polymer hydrogel.

Keywords: lithium-ion batteries, anode material, $\mathrm{SiO}_{\mathrm{x}}, \mathrm{PAA}-\mathrm{PANi}$, graphene, conductive hydrogel

\section{INTRODUCTION}

Lithium-ion batteries (LIBs), presumably among the most prospective devices for energy storage, are featured with higher energy density, longer cycle life, lower self-discharging, and more safety. Developing advanced LIBs with highly advanced energy density and cyclability is an immediate need for lightweight electronics and range expansion of electric vehicles. Yet the current graphite anode with an unsatisfactory specific capacity of $\sim 372 \mathrm{~mA} \mathrm{~h} \mathrm{~g}^{-1}$ $\left(\mathrm{LiC}_{6}\right)$ can't follow the development of modern equipment for high energy storage system (Casimir et al., 2016; Zuo et al., 2017; Han et al., 2018; Yi et al., 2018, 2019; Zheng et al., 2018, 2020; Xiao et al., 2019). Hence, silicon has become a potential candidate to replace commercial graphite anode for LIBs in that it has higher capacity $\left(\sim 4,200 \mathrm{~mA} \mathrm{~h} \mathrm{~g}^{-1}\right)$, suitable discharge platform $\left(\sim 0.4 \mathrm{~V}\right.$ vs. $\left.\mathrm{Li}^{\prime} / \mathrm{Li}^{+}\right)$and sufficient resources (Casimir et al., 2016; Jiang et al., 2016; Xu et al., 2018; An et al., 2019; Liu Y. et al., 2019a; Yang et al., 2019; Zhou et al., 2019; Zuo et al., 2019). Nevertheless, the two stubborn disadvantages of silicon, 
including the deterioration of electrode structure integrity as a result of gradual enhancement of pulverization happening in the repetition of discharge/charge process, as well as poor conductivity, have been the main obstacles to its application (Zhao et al., 2016; Zuo et al., 2017). To address the abovementioned key issues, a series of countermeasures have been taken, such as optimizing structure, doping and coating with carbon or other conductive materials.

Compared with $\mathrm{Si}$-based materials, $\mathrm{SiO}_{\mathrm{x}}$-based anodes are prone to achieve remarkable electrochemical performance due to the formation of $\mathrm{Li}_{2} \mathrm{O}$ and $\mathrm{Li}$ silicates, which can form the stable solid electrolyte interphase (SEI) layer and adapt to the volume expansion of $\mathrm{SiO}_{\mathrm{x}}$ during the insertion of $\mathrm{Li}^{+}$(Nguyen et al., 2013; Xu et al., 2017; Liu D. et al., 2019; Liu Y. et al., 2019b; Zheng et al., 2019). Although the capacity of $\mathrm{SiO}_{\mathrm{x}}$ is high, the volume multiplication usually causes this material to crack and pulverize. Besides, the low intrinsic conductivity of $\mathrm{SiO}_{\mathrm{x}}$ would lead to poor rate performance (Xu et al., 2017; Xiao et al., 2018; Fang et al., 2019; Li et al., 2019; Wang et al., 2020). Different ways have been adopted to overcome these issues, including doping the host framework with conductive particle, coating the electrodes with buffer materials, bettering the morphology, cutting the size of dimension and applying more effective binders. For example, Yu et al. obtained the pomegranate-liked nano-scale $\mathrm{SiO}_{\mathrm{x}}-\mathrm{C}$ by spray drying, the prepared composite presents a discharge specific capacity of $1,024 \mathrm{~mA} \mathrm{~h} \mathrm{~g}^{-1}$ when the current density is $500 \mathrm{~mA} \mathrm{~g}^{-1}$ after 200 cycles (Yu et al., 2018). Jiang et al. taken advantage of graphene bubbles to encapsulate the $\mathrm{SiO}_{\mathrm{x}}$ inside to accelerate ion transmission rate of the material, achieving $80 \%$ capacity retention after 1,000 cycles (Jiang et al., 2016).

Conducting polymers (CPs), such as polyaniline (PANi), polyacetylene, polythiophene (PTh), Polypyrrole (PPy), and et al., providing special $3 \mathrm{D}$ network nanostructures and high conductivity as a result of their large conjugated $\pi$ bonds structure ( $\mathrm{Li}$ et al., 2009; Li J. et al., 2018; Li P. et al.,
2018). At the same time, CPs have been verified as significant materials for the advancement of modern society, consisting of energy storage, semiconductor sensors and catalysis. For example, a PANi/CNT composite electrode synthesized via the way of in-situ chemical polymerization of aniline in a well-dispersed CNT solution revealed excellent electrochemical behavior. As the cathode material for LIBs, the PANi/CNT possessed a high energy density of $86 \mathrm{~mA} \mathrm{~h} \mathrm{~g}^{-1}$ at the 80th cycle and an average coulombic efficiency of $98 \%$ ( $\mathrm{Li}$ et al., 2009). Also, $\mathrm{SiO}_{\mathrm{x}}-\mathrm{PANi}-\mathrm{Ag}$ composite electrodes were synthesized by Zhang et al. via in-situ polymerization, and exhibited great cycling performances (with a reversible capacity of $1,149 \mathrm{~mA} \mathrm{~h} \mathrm{~g}^{-1}$ after 100 cycles) (Wang et al., 2014). Wu et al. prepared SiNP-PANi with a capacity retention rate of more than $90 \%$ after 5,000 cycles at a current density of $6.0 \mathrm{~A} \mathrm{~g}^{-1}$ (Wu et al., 2013).

Besides, the carbon bonds of graphene are sp2 hybridized, exhibiting a number of intriguing and unique properties such as high surface area, admirable electronic conductivity and superior mechanical properties (Huang et al., 2011; Li P. et al., 2018). It is very meaningful that the properties make graphene-based materials useful for modifying silicon-based materials (Jiang et al., 2016). For example, Zhu et al. constructed Si@SiO $/ \mathrm{GH}$ composite with a stable storage capacity of $1,020 \mathrm{~mA} \mathrm{~h} \mathrm{~g}^{-1}$ at $4 \mathrm{~A} \mathrm{~g}^{-1}$ (Zhu et al., 2019).

Herein, we provide a flexible and harmless method for synthesizing $\mathrm{SiO}_{\mathrm{x}}-\mathrm{G} / \mathrm{PAA}-\mathrm{PANi}$ /graphene (Scheme 1). Firstly, $\mathrm{SiO}_{\mathrm{x}}-\mathrm{G}$ was synthesized by a method of high-energy mechanical ball milling (Jiang et al., 2016). Then, Polyacrylic acid and Polyaniline are doped with each other by in-situ polymerization as a framework to synthesize $\mathrm{SiO}_{\mathrm{x}}-\mathrm{G} / \mathrm{PAA}-\mathrm{PANi}$. Finally, the graphene dispersion is added to obtain the $\mathrm{SiO}_{\mathrm{x}}-\mathrm{G} / \mathrm{PAA}-$ $\mathrm{PANi}$ /graphene. This intertwined doping not only can provide a continuous path for electron conduction, but also stabilize the material structure. Hence, the $\mathrm{SiO}_{\mathrm{x}}-\mathrm{G} / \mathrm{PAA}-\mathrm{PANi}$ /graphene exhibits superior electrochemical performance.

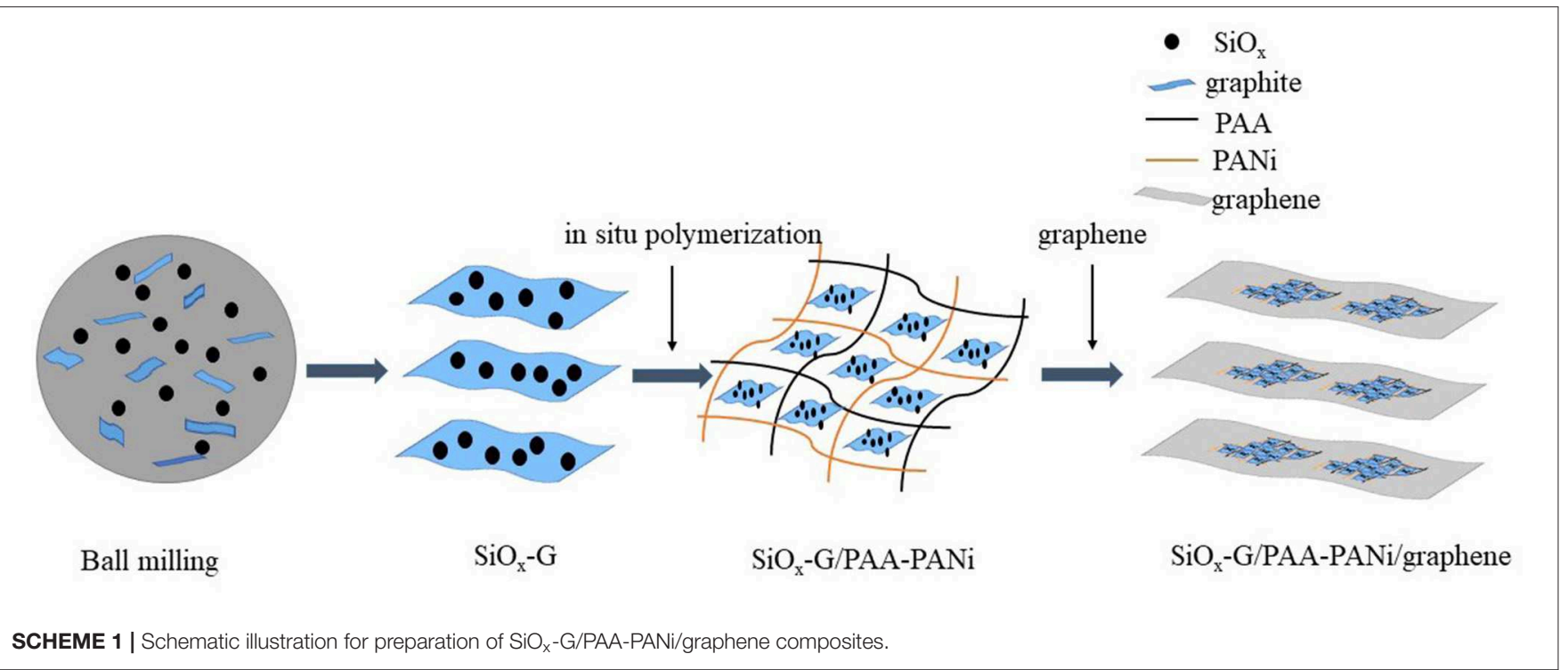




\section{EXPERIMENTAL}

\section{Material Preparation \\ Synthesis of $\mathrm{SiO}_{x}-\mathrm{G}$}

$\mathrm{SiO}_{\mathrm{x}}-\mathrm{G}$ was obtained by a solid state method. Firstly, $\mathrm{SiO}_{\mathrm{x}}$ is prepared by ball milling (QM-3SP4, Nanjing, China) $\mathrm{SiO}$ in $\mathrm{Ar}$ for $6 \mathrm{~h}(500 \mathrm{rpm}$, the ball-to-particulate weight ratio of 30:1). Secondly, $6.0 \mathrm{~g}$ of Graphite was heated at $600^{\circ} \mathrm{C}$ for $20 \mathrm{~min}$ in Ar flow and then mixed with $6.0 \mathrm{~g}$ of $\mathrm{SiO}_{\mathrm{x}}$ by ball milling for $6 \mathrm{~h}$ under the same ball milling conditions as the process for preparation of $\mathrm{SiO}_{\mathrm{x}}$. The above composite material is recorded as $\mathrm{SiO}_{\mathrm{x}}-\mathrm{G}$.

\section{Synthesis of $\mathrm{SiO}_{\mathrm{x}}-\mathrm{G} / \mathrm{PAA}-\mathrm{PANi}$}

Firstly, $0.005 \mathrm{~g}$ of PAA was weighed and dissolved in a $25 \mathrm{ml}$ beaker and placed in an oven at $60^{\circ} \mathrm{C}$ for $1 \mathrm{~h}$, and then an appropriate amount of $0.5 \mathrm{M} \mathrm{NaOH}$ was added. Secondly, $0.2 \mathrm{~g}$ of $\mathrm{SiO}_{\mathrm{x}}-\mathrm{G}$ was dissolved in the above sodium polyacrylate solution, and ultrasonicated for $1 \mathrm{~h}$, followed by stirring in an ice bath (Li P. et al., 2018). Subsequently, aniline and $\left(\mathrm{NH}_{4}\right)_{2} \mathrm{~S}_{2} \mathrm{O}_{8}$ were added and stirred for $40 \mathrm{~min}$. The target production was obtained after standing, dialysis, and lyophilization.

\section{Synthesis of $\mathrm{SiO}_{\mathrm{x}}-\mathrm{G} / \mathrm{PAA}-\mathrm{PANi} / \mathrm{Graphene}$}

The preparation steps are the same as the synthesis process of $\mathrm{SiO}_{\mathrm{x}}-\mathrm{G} / \mathrm{PAA}-\mathrm{PANi}$, except that the dispersion of $0.002 \mathrm{~g}$ of graphene is stirred for $1 \mathrm{~h}$ before standing. The obtained sample was named as $\mathrm{SiO}_{\mathrm{x}}-\mathrm{G} / \mathrm{PAA}-\mathrm{PANi} /$ graphene.

\section{Material Characterization}

The as-prepared product was characteristic of X-ray diffraction (XRD, D/max $2500 \mathrm{PC}$ ) with the use of $\mathrm{Cu} \mathrm{Ka}$ radiation. $\mathrm{X}$-ray photoelectron spectroscopy (XPS) data was recorded by the Electronic detection system (Thermo VG Scientific ESCA Lab 250). Thermogravimetric analysis (TGA) data is recorded from indoor temperature to $800^{\circ} \mathrm{C}$ at a rate of $10^{\circ} \mathrm{C} \mathrm{min}-1$ under an oxygen atmosphere. The data analysis of Fourier transform infrared (FT-IR) spectroscopy was undertaken by an IR spectrophotometer (Thermo Fisher, American). The morphology and element distribution are presented by highresolution field emission scanning electron microscopy (FESEM, Zeiss, Germany). Transmission electron microscopy (TEM) were performed on a JEOL 2100 worked at $200 \mathrm{kV}$.

\section{Electrochemical Measurements}

In preparation for the working electrode, the active material (75\%), the conductive agent (Acetylene black,10\%) and the binder (Sodium alginate,15\%) were uniformly mixed to obtain the slurry, and coated on the upper part of the current collector (copper foil) and placed in a vacuum oven at $105^{\circ} \mathrm{C}$ for $8 \mathrm{~h}$. CR2032-type coin half-cell was converged in a glove box filled with high purity argon $\left(\mathrm{O}_{2}\right.$ and $\left.\mathrm{H}_{2} \mathrm{O}<0.5 \mathrm{ppm}\right)$, with $1 \mathrm{M} \mathrm{LiPF}_{6}$ dissolved in ethylene carbonate: dimethyl carbonate: ethyl methyl

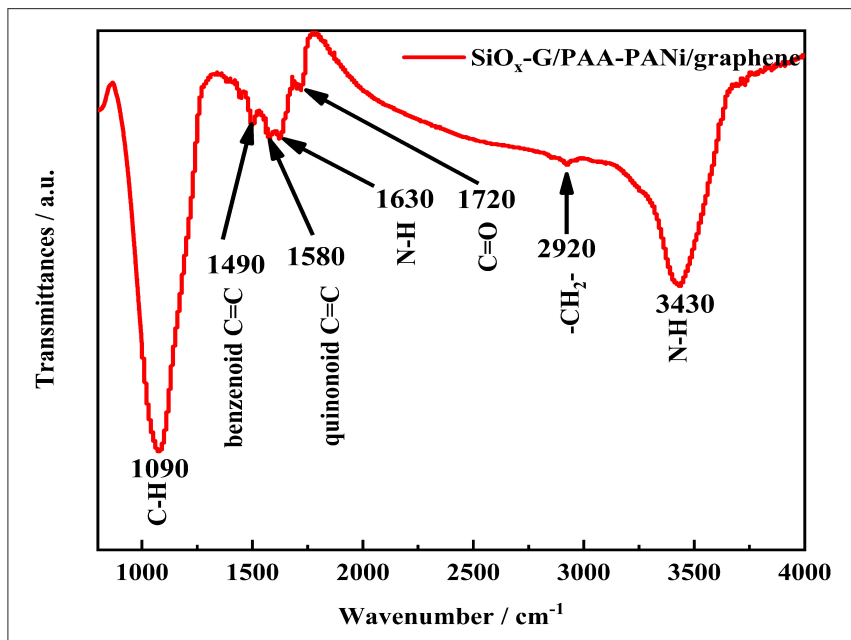

FIGURE 2 | FT-IR image of $\mathrm{SiO}_{x}$-G/PAA-PANi/graphene.
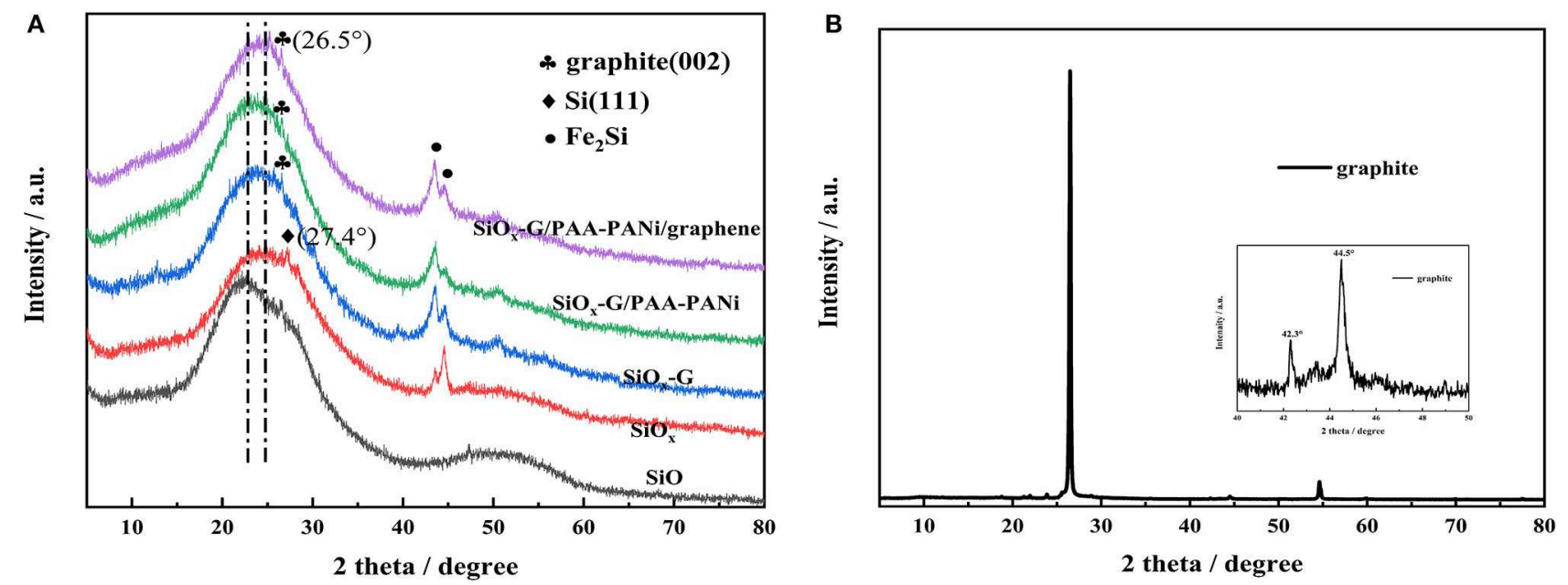

FIGURE 1 | (A) XRD image of $\mathrm{SiO}, \mathrm{SiO}_{x}, \mathrm{SiO}_{x}-\mathrm{G}, \mathrm{SiO}_{x}-\mathrm{G} / \mathrm{PAA}-\mathrm{PANi}$, and $\mathrm{SiO}_{\mathrm{x}}-\mathrm{G} / \mathrm{PAA}-\mathrm{PANi} /$ graphene; (B) XRD image of graphite. 
carbonate (1:1:1 in volume), and $10 \%$ of fluorinated ethylene carbonate was further added as the electrolyte, Celgard 2500 film as the separator, and lithium foil as the counter electrode. The cyclic stability test and rate performance test of the material can be achieved on Land-CT 2001A instrument where the potential is $0.01 \mathrm{~V}-3 \mathrm{~V}$ and the current density is $500 \mathrm{~mA} \mathrm{~g}^{-1}$ at $25^{\circ} \mathrm{C}$. Cyclic Voltammetry (CV) was recorded by electrochemical analyzer (CHI 604E, Chen He Instruments, Shanghai).

\section{RESULTS AND DISCUSSION}

XRD patterns of four samples were compared in Figure 1A. As illustrated, commercial silicon monoxide is amorphous, which is consistent with previous findings (Hwa et al., 2013; Yu et al., 2013). Compared with $\mathrm{SiO}$, the position of the broad peak of $\mathrm{SiO}_{\mathrm{x}}$ shifted from $22^{\circ}$ to $24.8^{\circ}$. Also, it is observed that there is a distinct characteristic peak of $\mathrm{Si}$ (111) located at $27.2^{\circ}$ in asobtained $\mathrm{SiO}_{\mathrm{x}}$ sample, which might be due to that a part of $\mathrm{SiO}$ is reduced to Si after ball milling (Jiang et al., 2016). In addition, two peaks at $43.4^{\circ}$ and $44.5^{\circ}$ were observed in $\mathrm{SiO}_{\mathrm{x}}$ samples, corresponding to the characteristic peak of $\mathrm{Fe}_{2} \mathrm{Si}$, which might be created from the stainless steel ball and Si during the process of ball milling. Similar phenomenon was also demonstrated by Qian et al. (2017). Figure 1B shows the XRD pattern of graphite. The crystal plane characteristic peak of graphite (002) is situated at $26.5^{\circ}$ in $\mathrm{SiO}_{\mathrm{x}}-\mathrm{G}, \mathrm{SiO}_{\mathrm{x}}-\mathrm{G} / \mathrm{PAA}-\mathrm{PANi}$ and $\mathrm{SiO}_{\mathrm{x}}-\mathrm{G} / \mathrm{PAA}-$ $\mathrm{PANi}$ /graphene samples (Figure 1A), showing that the existence of graphite in the three samples.

Fourier transform infrared (FT-IR) spectrum of $\mathrm{SiO}_{\mathrm{x}}-\mathrm{G} / \mathrm{PAA}-$ $\mathrm{PANi}$ /graphene is shown in Figure 2. The absorption peaks at 3,430 and $2,920 \mathrm{~cm}^{-1}$ correspond to the $\mathrm{N}-\mathrm{H}$ bending vibration absorption peak and $-\mathrm{CH}_{2}$ - stretching vibration absorption peak, respectively. In addition, the bands at 1,720 and 1,090 $\mathrm{cm}^{-1}$ are attributed to $\mathrm{C}=\mathrm{O}$ bending vibration and $\mathrm{C}-\mathrm{H}$ bending vibration. The presence of above several absorption peaks are sufficient to prove the existence of PAA (Wang et al., 2015). The weaker absorption peak from 1,400 to

TABLE 1 | The proportion of different valence states of Si in $\mathrm{SiO}_{\mathrm{x}}$-G/PAA-PANi/graphene.

\begin{tabular}{lrrrrr}
\hline Production & $\mathbf{S i}^{\mathbf{0}}$ & $\mathbf{S i}^{+\mathbf{1}}$ & $\mathbf{S i}^{+\mathbf{2}}$ & $\mathbf{S i}^{+\mathbf{3}}$ & $\mathbf{S i}^{+\mathbf{4}}$ \\
\hline Position/eV & 99.98 & 102.06 & 102.85 & 103.68 & 105.00 \\
Percentage/\% & 15.55 & 20.11 & 29.63 & 29.63 & 5.08 \\
\hline
\end{tabular}
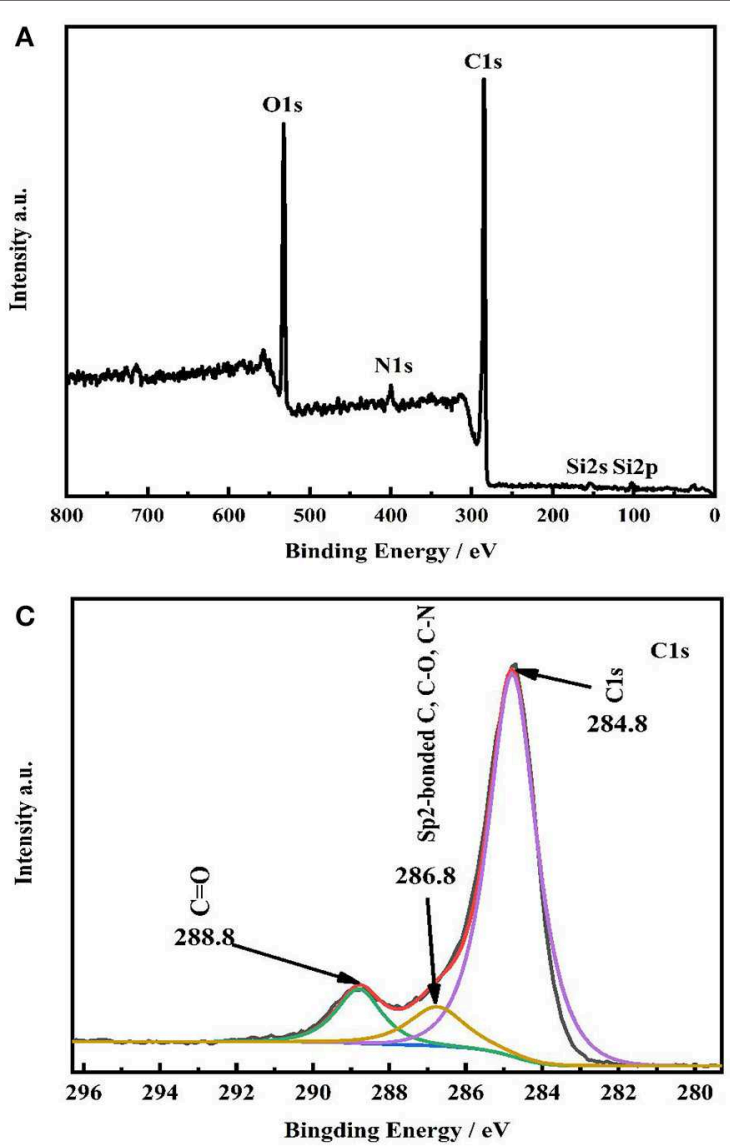
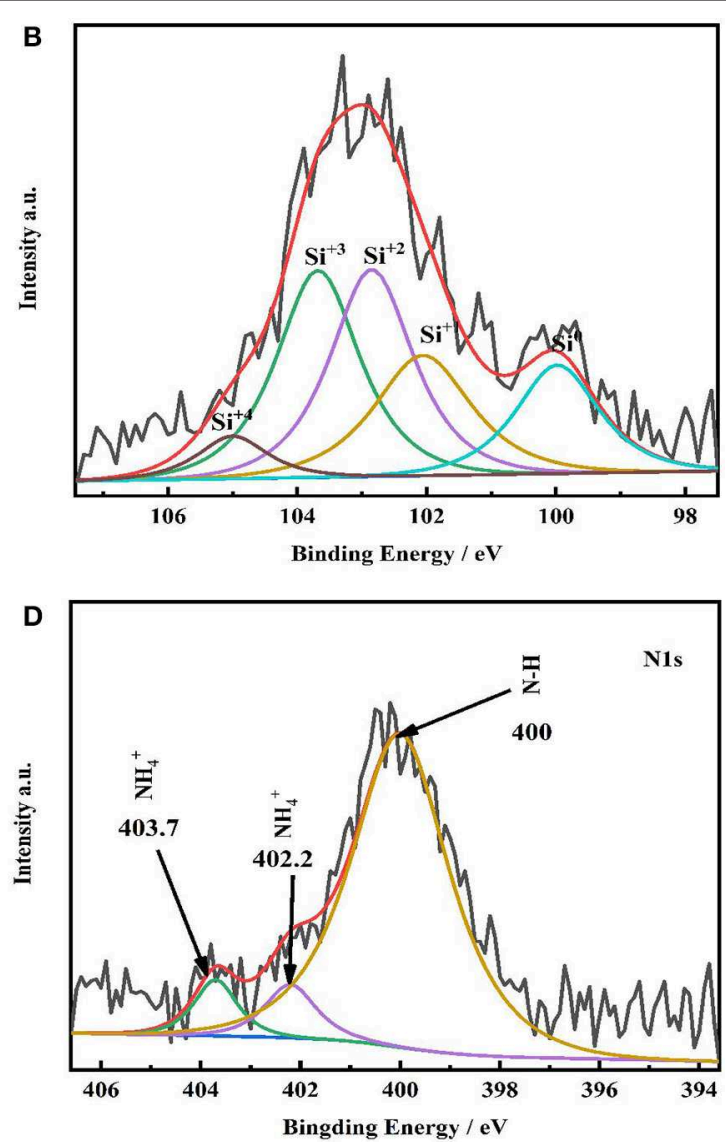

FIGURE 3 | (A-D) XPS spectra of $\mathrm{SiO}_{x}-\mathrm{G} / \mathrm{PAA}-\mathrm{PANi} /$ graphene particles. 
$1,650 \mathrm{~cm}^{-1}$ belongs to the polyaniline. The two characteristic bands at 1,490 and $1,580 \mathrm{~cm}^{-1}$ are attributed to the stretching vibration of benzenoid $\mathrm{C}=\mathrm{C}$ and the stretching vibration of quinonoid $\mathrm{C}=\mathrm{C}$, respectively. The band at $1,630 \mathrm{~cm}^{-1}$ can be assigned to N-H bending vibration ( $\mathrm{Li}$ et al., 1999; Sivakkumar and Kim, 2007). The results confirm that the insuit polymerization of PAA and aniline lead to the formation of PAA-PANi.

The element details of $\mathrm{SiO}_{\mathrm{x}}$-G/PAA-PANi/graphene were reflected by XPS. Figure 3 shows the spectrum of all elements (Figure 3A), Si2p (Figure 3B), C1s (Figure 3C), and N1s (Figure 3D). The detail information about valence states of $\mathrm{Si}$ obtained from Figure 3B and described in Table 1. Clearly, the existence of $\mathrm{Si}^{0}(99.98 \mathrm{eV}), \mathrm{Si}^{1+}(102.06 \mathrm{eV}), \mathrm{Si}^{2+}(102.85 \mathrm{eV})$, $\mathrm{Si}^{3+}(103.68 \mathrm{eV})$, and $\mathrm{Si}^{4+}(105.00 \mathrm{eV})$ can be observed in the $\mathrm{SiO}_{\mathrm{x}^{-}}$ G/PAA-PANi/graphene sample, and the corresponding atomic percentages are $15.55,20.11,29.63,29.63$, and $5.08 \%$, respectively (Zheng et al., 2018). The average valence of Si calculated from the $\mathrm{Si} 2 \mathrm{p}$ spectrum is 1.88 . The XPS results of Figure 3B verifies the successful synthesis of $\mathrm{SiO}_{\mathrm{x}}$ from the commercial $\mathrm{SiO}$. The three peaks (Sp2-bonded C, C-O and C-N) deconvoluted from the $\mathrm{C} 1 \mathrm{~s}$ (Figure 3C) spectrum are situated at $286.75 \mathrm{eV}$, and $\mathrm{C}=\mathrm{O}$ located at $288.8 \mathrm{eV}$. The bonding energy of $\mathrm{C} 1 \mathrm{~s}$ for graphite is located at $284.8 \mathrm{eV}$, indicating that graphite is present in $\mathrm{SiO}_{\mathrm{x}}-\mathrm{G} / \mathrm{PAA}-\mathrm{PANi}$ /graphene. It can be obtained from the N1s spectrum (Figure 3D) that there is a strong peak at $400.00 \mathrm{eV}$, being in correspondence with the characteristic chemical N-H of PANi. The protonated amines are located at 402.20 and $403.70 \mathrm{eV}$. N1s spectrum (Figure 3D) and FT-IR (Figure 2) images further confirmed the successful preparation of PAAPANi by in-situ polymerization.

Figures 4a,b shows the SEM images of $\mathrm{SiO}_{\mathrm{x}}-\mathrm{G} / \mathrm{PAA}-$ $\mathrm{PANi}$ /graphene. As clearly seen, graphene is distributed around $\mathrm{SiO}_{\mathrm{X}}-\mathrm{G} / \mathrm{PAA}-\mathrm{PANi}$, which plays a supporting connection in the structure and can improve the conductivity. This results match with the results shown by the TEM (Figures $4 \mathbf{c}, \mathbf{d}$ ). Figure $4 c$ shows the TEM image of $\mathrm{SiO}_{\mathrm{x}}-\mathrm{G} / \mathrm{PAA}-\mathrm{PANi}$. As obtained from

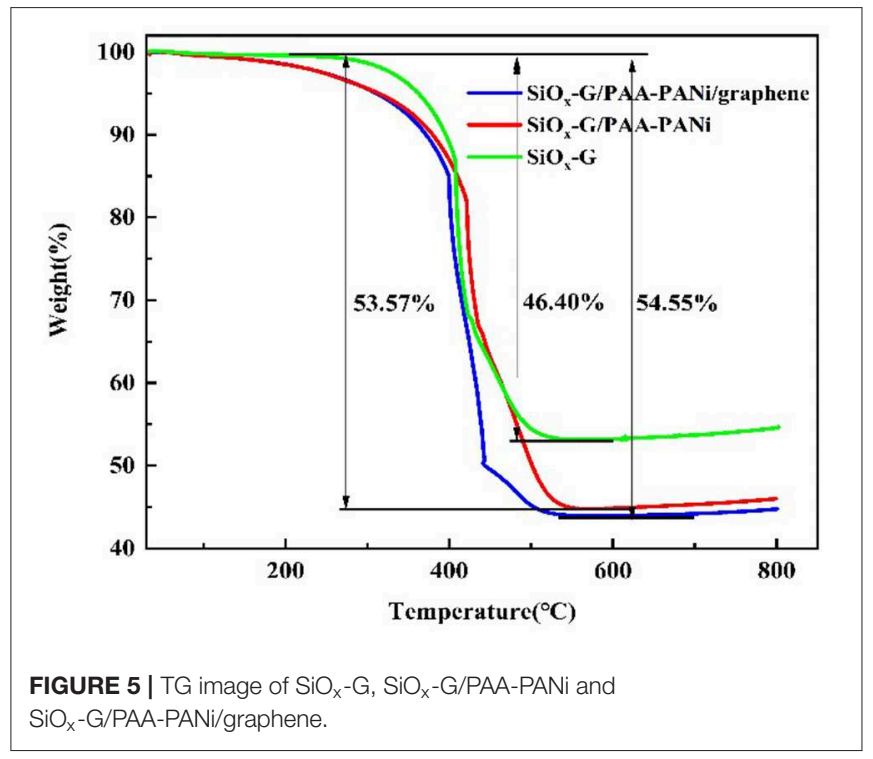

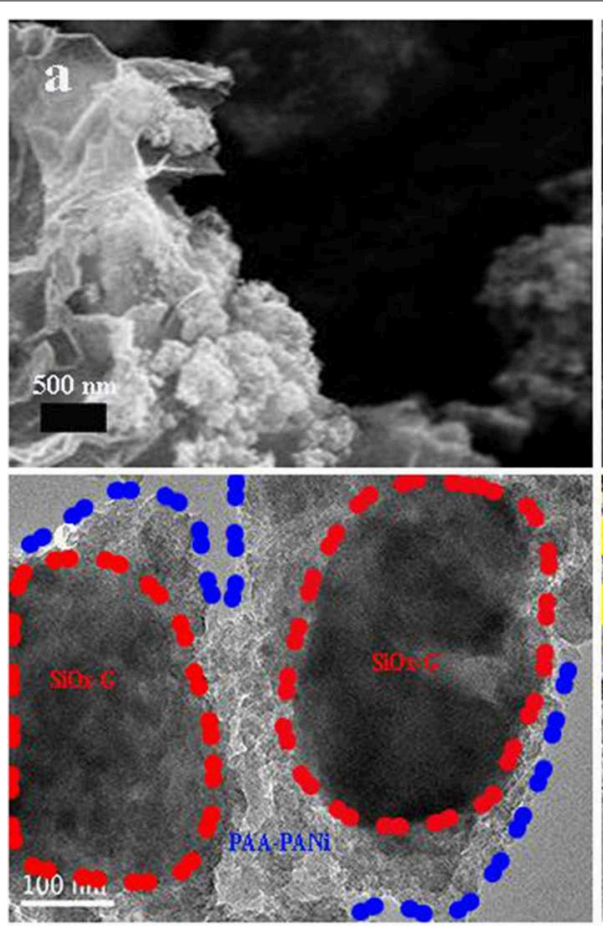

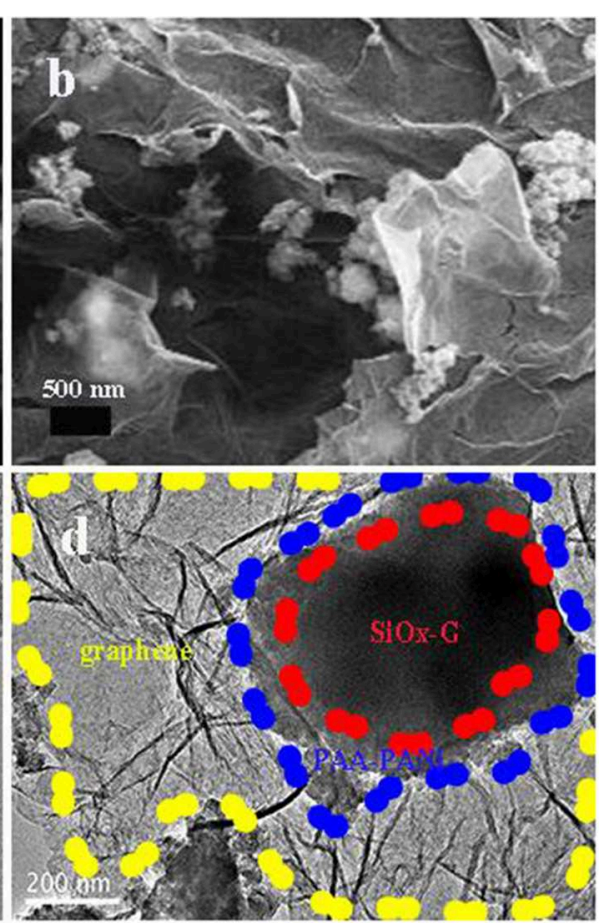

FIGURE 4 | (a,b) SEM images of $\mathrm{SiO}_{x}$-G/PAA-PANi/graphene; (c) TEM image of $\mathrm{SiO}_{x}-\mathrm{G} / \mathrm{PAA}-\mathrm{PANi}$; (d) TEM image of $\mathrm{SiO}_{\mathrm{x}}$-G/PAA-PANi/graphene. 
Figure 4a, the $\mathrm{SiO}_{\mathrm{x}}-\mathrm{G}$ particles are encapsulated inside the conductive hydrogel, and the coating thickness range of PAAPANi ranges from $100 \mathrm{~nm}$ to $200 \mathrm{~nm}$. Figure 4d depicts the TEM image of $\mathrm{SiO}_{\mathrm{x}}-\mathrm{G} / \mathrm{PAA}-\mathrm{PANi} / \mathrm{graphene}$. It can be observed that $\mathrm{SiO}_{\mathrm{X}}-\mathrm{G} / \mathrm{PAA}-\mathrm{PANi}$ particles are distributed between graphene.

The estimate of the carbon contents based on the three samples was obtained via TG measurement. The carbon contents of $\mathrm{SiO}_{\mathrm{x}}-\mathrm{G}, \mathrm{SiO}_{\mathrm{x}}-\mathrm{G} / \mathrm{PAA}-\mathrm{PANi}$, and $\mathrm{SiO}_{\mathrm{x}}-\mathrm{G} / \mathrm{PAA}-\mathrm{PANi} /$ graphene were about 46.85, 55.22, and 56.08 wt\%, respectively (Figure 5). The superficial passivation of $\mathrm{SiO}_{\mathrm{x}}$ lead to the oxidation of $\mathrm{Si}$ in air was not distinguished between 600 and $800^{\circ} \mathrm{C}$ (Chen et al., 2014; He et al., 2019; Jiang Y. et al., 2019; Jiang Z. et al., 2019). They are beneficial to improve the cycle performance of $\mathrm{SiO}$ to varying degrees.

Figure 6 displays the charge/discharge curves for $\mathrm{SiO}_{\mathrm{x}}$ G/PAA-PANi/graphene, $\mathrm{SiO}_{\mathrm{x}}$-G/PAA-PANi and $\mathrm{SiO}$ at a current density of $100 \mathrm{~mA} \mathrm{~g}^{-1}$. The charge/discharge curves of the

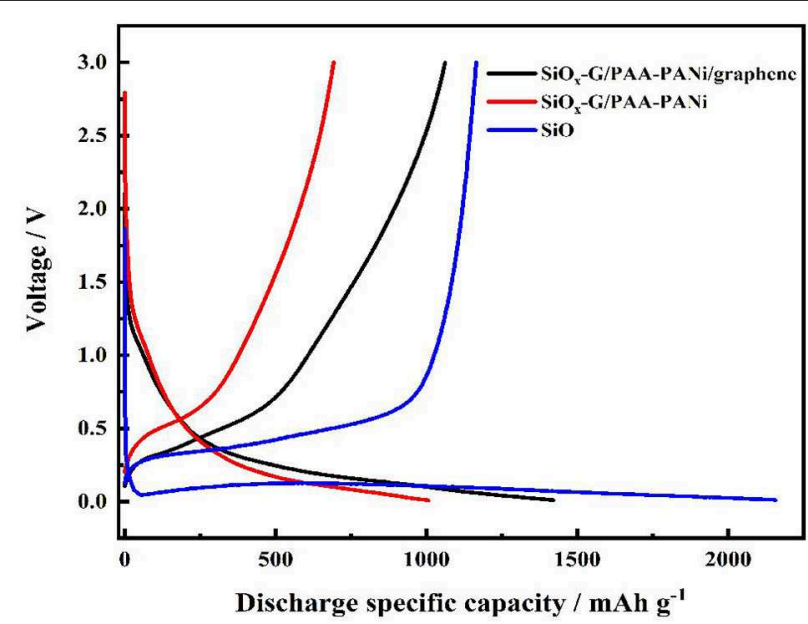

FIGURE 6 | The charge/discharge curves of $\mathrm{SiO}_{x}-\mathrm{G} / \mathrm{PAA}-\mathrm{PANi} / \mathrm{graphene}$, $\mathrm{SiO}_{\mathrm{x}}-\mathrm{G} / \mathrm{PAA}-\mathrm{PANi}$, and $\mathrm{SiO}$ anodes under the current density of $500 \mathrm{~mA} \mathrm{~g}^{-1}$
$\mathrm{SiO}$ electrode deliver a high initial discharge specific capacity of $2,156 \mathrm{~mA} \mathrm{~h} \mathrm{~g}$ and an initial charge specific capacity of $1,165 \mathrm{~mA} \mathrm{~h} \mathrm{~g}^{-1}$ (ICE is 54\%) and show a stable and obvious voltage platform around $0.1 \mathrm{~V}$, in which the gentle slopes appears between 0.2 and $0.5 \mathrm{~V}$. The first discharge-charge profiles of the $\mathrm{SiO}_{\mathrm{x}}-\mathrm{G} / \mathrm{PAA}-\mathrm{PANi}$ and $\mathrm{SiO}_{\mathrm{x}}-\mathrm{G} / \mathrm{PAA}-\mathrm{PANi}$ /graphene electrodes are similar to that of the $\mathrm{Si}-\mathrm{SiO}_{\mathrm{x}}$-Cristobalite/Graphite electrode (Ren and Li, 2014). The first discharge and charge capacities of $\mathrm{SiO}_{\mathrm{x}}-\mathrm{G} / \mathrm{PAA}-\mathrm{PANi}$ composite are 1006.4 and $692.3 \mathrm{~mA} \mathrm{~h} \mathrm{~g}{ }^{-1}$, respectively, with an ICE of about $68.8 \%$. The capacity of the first discharge and charge capacity of $\mathrm{SiO}_{\mathrm{x}}$-G/PAA-PANi/graphene is 1420.8 and $1062.3 \mathrm{~mA} \mathrm{~h} \mathrm{~g}^{-1}$, respectively, with an ICE of about $74.77 \%$. The large initial irreversible capacity is ascribed to the $\mathrm{Li}^{+}$consumption of to form the SEI film as well as the chemical reactions between $\mathrm{Li}$ and $\mathrm{SiO}_{\mathrm{x}}$.

Figure 7A displays the cyclic voltammetry curves of the $\mathrm{SiO}_{\mathrm{x}}$ G/PAA-PANi. A relatively flat reduction peak appearing at $1.2 \mathrm{~V}$ and a strong reduction peak appearing at $0.65 \mathrm{~V}$ in the first lithiation process are corresponding to the decomposition of liquid electrolytes and formation of the SEI film, respectively (Ren and Li, 2014). The oxidation peak appearing at $0.18 \mathrm{~V}$ indicates that $\mathrm{Li}$ is detached from $\mathrm{Li}_{\mathrm{x}} \mathrm{C}$, and the voltage position representing $\mathrm{Li}$ detached from $\mathrm{Li}_{\mathrm{X}} \mathrm{Si}$ is at $0.6 \mathrm{~V}$ in the first delithiation (Sivakkumar and Kim, 2007; Chen et al., 2014, 2018; Li et al., 2019). The reason for the incomplete reversibility of the electrode capacity is attributed to the by-products $\left(\mathrm{Li}_{2} \mathrm{O}\right.$ and $\mathrm{Li}_{2} \mathrm{Si}_{2} \mathrm{O}_{5}$ ) formed by the irreversible chemical reactions between $\mathrm{SiO}_{\mathrm{x}}$ and $\mathrm{Li}$ (Sivakkumar and Kim, 2007). There are two reduction peaks around $0.6 \mathrm{~V}$ and $0.2 \mathrm{~V}$, which represent the lithiation process. Figure $7 \mathbf{B}$ shows the cyclic voltammetry curves of the $\mathrm{SiO}_{\mathrm{x}}-\mathrm{G} / \mathrm{PAA}-\mathrm{PANi} /$ graphene composite. Comparing with the $\mathrm{CV}$ curves of the $\mathrm{SiO}_{\mathrm{x}^{-}}$ G/PAA-PANi, there are the same reduction peaks around 0.6 and $0.2 \mathrm{~V}$ in the first cycle of $\mathrm{SiO}_{\mathrm{x}}-\mathrm{G} / \mathrm{PAA}-\mathrm{PANi} /$ graphene, which are attributed to lithium extraction from the $\mathrm{SiO}_{\mathrm{x}^{-}}$ G/PAA-PANi/graphene.

The rate performance of the $\mathrm{SiO}_{\mathrm{x}}-\mathrm{G} / \mathrm{PAA}-\mathrm{PANi}$ /graphene, $\mathrm{SiO}_{\mathrm{X}}-\mathrm{G} / \mathrm{PAA}-\mathrm{PANi}$, and $\mathrm{SiO}$ electrodes is illustrated in Figure 8.
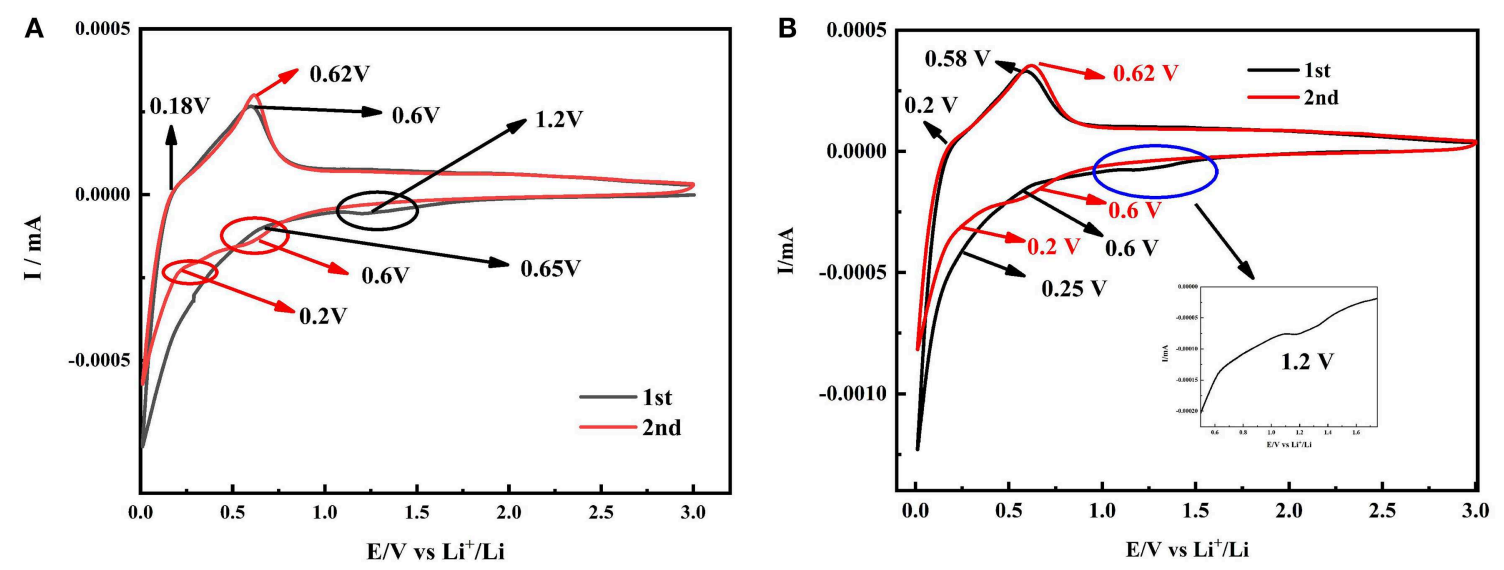

FIGURE 7 | CV curves of $\mathrm{SiO}_{\mathrm{x}}-\mathrm{G} / \mathrm{PAA}-\mathrm{PANi}(\mathbf{A})$ and $\mathrm{SiO}_{\mathrm{x}}-\mathrm{G} / \mathrm{PAA}-\mathrm{PANi} /$ graphene $(\mathbf{B})$ electrodes at the scanning rate of $0.1 \mathrm{mV} \mathrm{s}^{-1}$. 


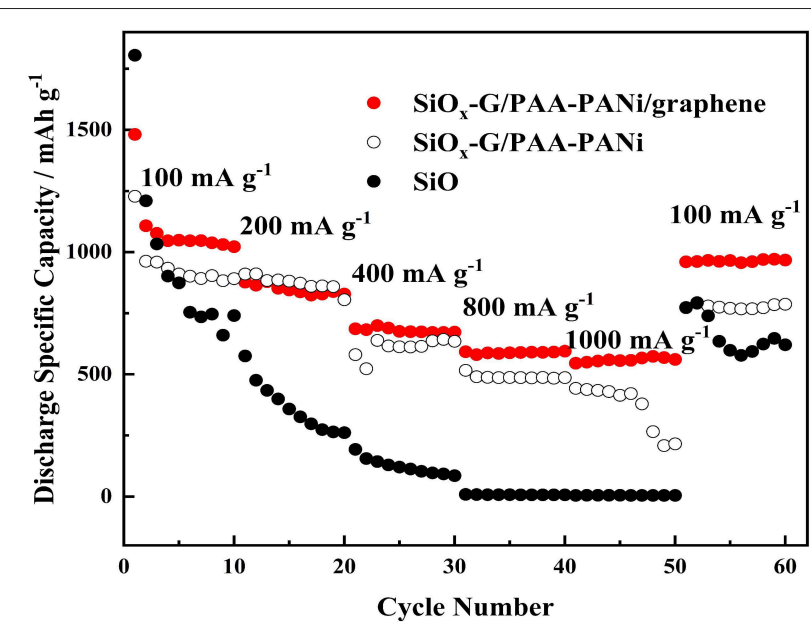

FIGURE 8 | The rate performances of $\mathrm{SiO}_{x}-\mathrm{G} / \mathrm{PAA}-\mathrm{PANi} /$ graphene, $\mathrm{SiO}_{x}-\mathrm{G} / \mathrm{PAA}-\mathrm{PANi}$, and $\mathrm{SiO}$ electrodes.

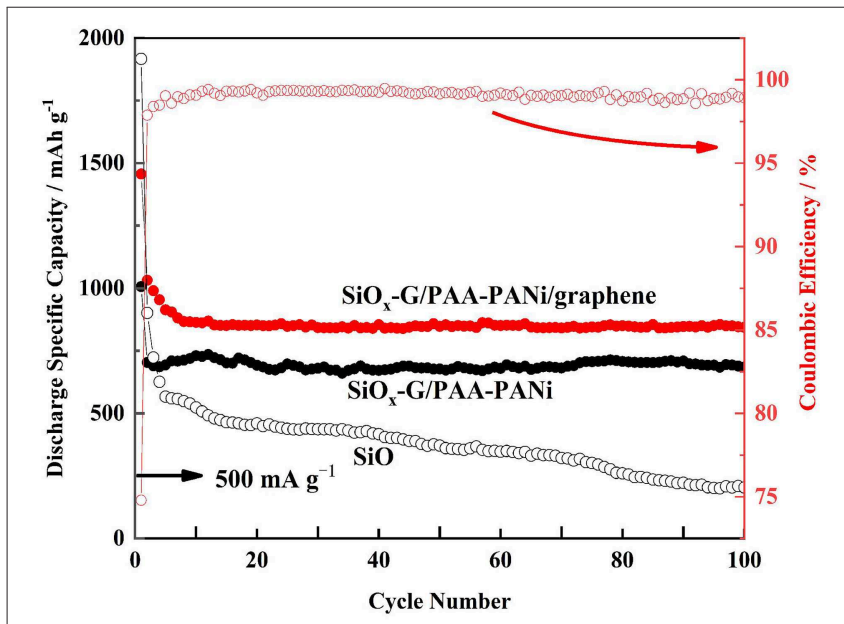

FIGURE 9 | Long-time cycling performances (discharge capacities) of $\mathrm{SiO}_{\mathrm{x}}-\mathrm{G} / \mathrm{PAA}-\mathrm{PANi} / \mathrm{graphene}, \mathrm{SiO}_{\mathrm{x}}-\mathrm{G} / \mathrm{PAA}-\mathrm{PANi}$, and $\mathrm{SiO}$ under the current density of $500 \mathrm{~mA} \mathrm{~g}^{-1}$.

The rate performance of the $\mathrm{SiO}$ electrode is significantly different from that of the $\mathrm{SiO}_{\mathrm{x}}-\mathrm{G} / \mathrm{PAA}-\mathrm{PANi}$ electrode, in which the rate performance of the $\mathrm{SiO}$ electrode is so unsatisfactory. Based on these results, the doping of conductive graphene further enhances the rate performance. The capacities of the $\mathrm{SiO}_{\mathrm{x}}$ G/PAA-PANi/graphene are 1022.3, 828.1, 675.7, 588.1, 556.2 mA $\mathrm{h} \mathrm{g}^{-1}$ at a current density of $100,200,400,800$, and $1,000 \mathrm{~mA} \mathrm{~g}^{-1}$, respectively. Moreover, the capacity can rise to $967.1 \mathrm{~mA} \mathrm{~h} \mathrm{~g}^{-1}$ as the current density returns to $100 \mathrm{~mA} \mathrm{~g}^{-1}$, which demonstrates that $\mathrm{SiO}_{\mathrm{x}}-\mathrm{G} / \mathrm{PAA}-\mathrm{PANi}$ /graphene electrode can maintain a good structural stability.

\section{REFERENCES}

An, C., Yuan, Y., Zhang, B., Tang, L., Xiao, B., He, Z., et al. (2019). Graphene wrapped $\mathrm{FeSe}_{2}$ nano-microspheres with high pseudocapacitive
Figure 9 indicates the cycling stability of $\mathrm{SiO}_{\mathrm{x}}-\mathrm{G} / \mathrm{PAA}-$ PANi/graphene, $\mathrm{SiO}_{\mathrm{x}}-\mathrm{G} / \mathrm{PAA}-\mathrm{PANi}$, and $\mathrm{SiO}$ electrodes at a current density of $500 \mathrm{~mA} \mathrm{~g}^{-1}$. Although the initial discharge specific capacity of the $\mathrm{SiO}$ electrode reaches $1916.6 \mathrm{~mA} \mathrm{~h} \mathrm{~g}^{-1}$, the capacity suddenly drops due to the rupture of the $\mathrm{SiO}$ structure. Compared with $\mathrm{SiO}$, the cycle performance of $\mathrm{SiO}_{\mathrm{x}^{-}}$ G/PAA-PANi is significantly improved, and a high discharge specific capacity $\left(685.4 \mathrm{~mA} \mathrm{~h} \mathrm{~g}^{-1}\right)$ is maintained when it is cycled to the 100th cycle, which can be attributed to the $3 \mathrm{D}$ structure of the conductive hydrogel that can serve as an effective buffer for the volume change of $\mathrm{SiO}_{\mathrm{x}}$ nanoparticles. In contrast to $\mathrm{SiO}_{\mathrm{x}}$-G/PAA-PANi, $\mathrm{SiO}_{\mathrm{x}}-\mathrm{G} / \mathrm{PAA}-\mathrm{PANi}$ /graphene exhibits a significantly improved performance, with a discharge specific capacity of $842.3 \mathrm{~mA} \mathrm{~h} \mathrm{~g}^{-1}$ at current density of $500 \mathrm{~mA} \mathrm{~g}^{-1}$ at 100 th cycle, and the coulombic efficiency is about $99 \%$ from 8 th to 100 th cycles, which is due to the improved electron transport.

\section{CONCLUSIONS}

In summary, the three-dimensional $\mathrm{SiO}_{\mathrm{x}}-\mathrm{G} / \mathrm{PAA}-$ $\mathrm{PANi}$ /graphene hydrogel was prepared by a facile ball milling and in-situ polymerization process. The amorphous $\mathrm{SiO}_{\mathrm{x}}-\mathrm{G}$ was encapsulated within 3D mesh structure of PAA-PANi/graphene. According to the preparation method of the study, the specific capacity of $\mathrm{SiO}_{\mathrm{x}}-\mathrm{G} / \mathrm{PAA}-\mathrm{PANi} /$ graphene can be as high as $842.3 \mathrm{~mA} \mathrm{~h} \mathrm{~g}^{-1}$ at $500 \mathrm{~mA} \mathrm{~g}^{-1}$ when $\mathrm{Li}^{+}$are subjected to the 100th deintercalation, as well as the ICE is increased to $74.77 \%$ compared with $\mathrm{SiO}$. The superior performance could be due to that PAA-PANi offers fast channels for electronic and ionic transfer and free space for $\mathrm{SiO}_{\mathrm{x}}-\mathrm{G}$ volume changes, and also the conductively active graphene effectively improves the electron transport.

\section{DATA AVAILABILITY STATEMENT}

The raw data supporting the conclusions of this article will be made available by the authors, without undue reservation, to any qualified researcher.

\section{AUTHOR CONTRIBUTIONS}

YR contributed conception, design of the study, and revised the manuscript. YL carried out experiments and wrote the manuscript. KL performed analyzed experimental results. $\mathrm{XH}$ revised the manuscript.

\section{FUNDING}

This work was financially supported by the National Nature Science Foundation of China (21576030 and U1607127).

contribution for enhanced Na-ion storage. Adv. Energy Mater. 9:1900356. doi: 10.1002/aenm.201900356

Casimir, A., Zhang, H., Ogoke, O., Amine, J., Lu, J., and Wu, G. (2016). Silicon-based anodes for lithium-ion batteries: effectiveness of 
materials synthesis and electrode preparation. Nano Energy 27, 359-376. doi: 10.1016/j.nanoen.2016.07.023

Chen, D., Yi, R., Chen, S., Xu, T., Gordin, M., and Wang, D. (2014). Facile synthesis of graphene-silicon nanocomposites with an advanced binder for high-performance lithium-ion battery anodes. Solid State Ionics. 254, 65-71. doi: 10.1016/j.ssi.2013.11.020

Chen, Y., Mao, Q., Bao, L., Yang, T., Lu, X., Du, N., et al. (2018). Rational design of coaxial MWCNTs@Si/SiO $\mathrm{S}_{\mathrm{x}} @ \mathrm{C}$ nanocomposites as extending-life anode materials for lithium-ion batteries. Ceram. Int. 44, 16660-16667. doi: 10.1016/j.ceramint.2018.06.093

Fang, R., Miao, C., Mou, H., and Xiao, W. (2019). Facile synthesis of

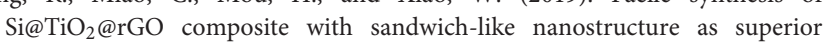
performance anodes for lithium ion batteries. J. Alloys. Compd. 818:152884. doi: 10.1016/j.jallcom.2019.152884

Han, X., Cui, X., Yi, T., Li, Y., and Yue, C. (2018). Recent progress of $\mathrm{NiCo}_{2} \mathrm{O}_{4}$ based anodes for high-performance lithium-ion batteries. Curr. Opin. Solid State Mater Sci. 22, 109-126. doi: 10.1016/j.cossms.2018.05.005

He, X., Sun, Z., Zou, Q., Yang, J., and Wu, L. (2019). Codeposition of nanocrystalline Co-Ni catalyst based on 1-ethyl-3-methylimidazolium bisulfate and ethylene glycol system for hydrogen evolution reaction. J. Electrochem. Soc. 166, D908-D915. doi: 10.1149/2.0171916jes

Huang, X., Yin, Z., Wu, S., Qi, X., He, Q., Zhang, Q., et al. (2011). Graphenebased materials: synthesis, characterization, properties, and applications. Small 7, 1876-1902. doi: 10.1002/smll.201002009

Hwa, Y., Park, C., and Sohn, H. (2013). Modified $\mathrm{SiO}$ as a high performance anode for Li-ion batteries. J. Power Sour. 22, 129-134. doi: 10.1016/j.jpowsour.2012.08.060

Jiang, B., Zeng, S., Wang, H., Liu, D., Qian, J., Cao, Y., et al. (2016). Dual core-shell structured $\mathrm{Si} @ \mathrm{SiO}_{\mathrm{x}} @ \mathrm{C}$ nanocomposite synthesized via a onestep pyrolysis method as a highly stable anode material for lithium-ion batteries. Appl. Mater. Interfaces 8, 31611-31616. doi: 10.1021/acsami.6b 09775

Jiang, Y., Feng, X., Cheng, G., Li, Y., Li, C., He, Z., et al. (2019). Electrocatalytic activity of $\mathrm{MnO}_{2}$ nanosheet array-decorated carbon paper as superior negative electrode for vanadium redox flflow Batteries. Electrochim. Acta. 322:134754. doi: 10.1016/j.electacta.2019.134754

Jiang, Z., Li, Y., Zhu, J., Li, B., Li, C., Wang, L., et al. (2019). Synthesis and performance of a graphene decorated $\mathrm{NaTi}_{2}\left(\mathrm{PO}_{4}\right)_{3} / \mathrm{C}$ anode for aqueous lithium-ion batteries. Alloys J. Compd. 791, 176-183. doi: 10.1016/j.jallcom.2019.03.289

Li, C., Bai, H., and Shi, G. (2009). Conducting polymer nanomaterials: electrosynthesis and applications. Chem. Soc. Rev. 38, 2397-2409. doi: $10.1039 / \mathrm{b} 816681 \mathrm{c}$

Li, D., Jiang, Y., Li, C., Wu, Z., Chen, X., and Li, Y. (1999). Self-assembly of polyaniline/polyacrylic acid films via acid-base reaction induced deposition. Polymer 40, 7065-7070. doi: 10.1016/S0032-3861(99)00118-4

Li, J., Zhang, G., Yang, Y., Yao, D., Lei, Z., Li, S., et al. (2018). Glycinamide modified polyacrylic acid as high-performance binder for silicon anodes in lithium-ion batteries. Power Sour. J. 406, 102-109. doi: 10.1016/j.jpowsour.2018.10.057

Li, P., Jin, Z., Peng, L., Zhao, F., Xiao, D., Jin, Y., et al. (2018). Stretchable all-gel-state fiber-shaped supercapacitors enabled by macromolecularly interconnected 3D graphene/nanostructured conductive polymer hydrogels. Adv. Mater.20181800124. doi: 10.1002/adma.201800124

Li, R., Xiao, W., Miao, C., Fang, R., Wang, Z., and Zhang, M. (2019). Sphere-like $\mathrm{SnO}_{2} / \mathrm{TiO}_{2}$ composites as high-performance anodes for lithium ion batteries. Ceram. Int. 45, 13530-13535. doi: 10.1016/j.ceramint.2019. 04.059

Liu, D., Fan, X., Li, Z., Liu, T., Ling, M., Liu, Y., et al. (2019). A cation/anion codoped $\mathrm{Li}_{1.12} \mathrm{Na}_{0.08} \mathrm{Ni}_{0.2} \mathrm{Mn}_{0.6} \mathrm{O}_{1.95} \mathrm{~F}_{0.05}$ cathode for lithium ion batteries. Nano Energy 58, 786-796. doi: 10.1016/j.nanoen.2019.01.080

Liu, Y., Fan, X., Zhang, Z., Wu, H., Liu, D., Dou, A., et al. (2019b). Enhanced electrochemical performance of Li-rich layered cathode materials by combined Cr doping and $\mathrm{LiAlO}_{2}$ coating. ACS Sustainable Chem. Eng. 7, 2225-2235. doi: 10.1021/acssuschemeng.8b04905

Liu, Y., Tang, L., Wei, H., Zhang, X., He, Z., Li, Y., et al. (2019a). Enhancement on structural stability of Ni-Rich cathode materials by in-situ fabricating dual-modified layer for lithium-ion batteries. Nano Energy 65:104043. doi: $10.1016 /$ j.nanoen.2019.104043
Nguyen, D., Nguyen, C., Kim, J., Kim, J., and Song, S. (2013). Facile synthesis and high anode performance of carbon fiber-interwoven amorphous nano$\mathrm{SiO}_{\mathrm{x}} /$ graphene for rechargeable lithium batteries. ACS Appl. Mater. Interfaces 5, 11234-11239. doi: 10.1021/am4034763

Qian, L., Lan, J., Xue, M., Yu, Y., and Yang, X. (2017). Two-step ballmilling synthesis of a $\mathrm{Si} / \mathrm{SiO}_{\mathrm{x}} / \mathrm{C}$ composite electrode for lithium ion batteries with excellent long-term cycling stability. RSC Adv. 7, 36697-36704. doi: 10.1039/C7RA06671F

Ren, Y., and Li, M. (2014). Si-SiO ${ }_{\mathrm{x}}$-cristobalite/graphite composite as anode for $\mathrm{Li}$ ion batteries. Electrochim. Acta. 142, 11-17. doi: 10.1016/j.electacta.2014.07.101

Sivakkumar, S., and Kim, D. (2007). Polyaniline/carbon nanotube composite cathode for rechargeable lithium polymer batteries assembled with gel polymer electrolyte. J. Electrochem. Soc. 54:A134. doi: 10.1149/1.2404901

Wang, K., Huang, X., Zhou, T., Wang, H., Xie, H., and Ren, Y. (2020). Boosted electrochemical properties of porous $\mathrm{Li}_{2} \mathrm{FeSiO}_{4} / \mathrm{C}$ based on Fe-MOFs precursor for lithium ion batteries. Vacuum. 171:108997. doi: 10.1016/j.vacuum.2019.108997

Wang, L., Zhang, P., Su, L., and Ma, C. (2014). $\mathrm{SiO}_{\mathrm{x}}-\mathrm{PANI}-\mathrm{Ag}$ composites with Homogeneously-embedded $\mathrm{Si}$ nanocrystals and nanopores as highperformance anodes for lithium ion batteries. J. Mater. Chem. A 2, 3776-3782. doi: $10.1039 / \mathrm{c} 3 \operatorname{ta} 14498 \mathrm{~d}$

Wang, Y., Wang, X., Tang, S., and Vongehr, S. (2015). Highly processible and electrochemically active graphene-doped polyacrylic acid/polyaniline allowing the preparation of defect-free thin films for solid-state supercapacitors. RSC Adv. 5, 62670-62677. doi: 10.1039/C5RA05486A

Wu, H., Yu, G., Pan, L., Liu, N., McDowell, M., Bao, Z., et al. (2013). Stable Li-ion battery anodes by in-situ polymerization of conducting hydrogel to conformally coat silicon nanoparticles. Nat. Commun. 4:1943. doi: 10.1038/ncomms2941

Xiao, B., Wang, P., Zhang, B., He, Z., Yang, Z., Tang, L., et al. (2019). Effect of $\mathrm{MgO}$ and $\mathrm{TiO}_{2}$ coating on electrochemical performance of $\mathrm{Li}$ Rich cathode materials for lithium-ion batteries. Energy Technol. 7:1800829. doi: $10.1002 /$ ente. 201800829

Xiao, W., Wang, Z., Zhang, Y., Fang, R., Yuan, Z., Miao, C., et al. (2018). Enhanced performance of $\mathrm{P}(\mathrm{VDF}-\mathrm{HFP})$-based composite polymer electrolytes doped with organic-inorganic hybrid particles $\mathrm{PMMA}-\mathrm{ZrO}_{2}$ for lithium ion batteries. J. Power Sour. 382, 128-134. doi: 10.1016/j.jpowsour.2018.02.012

Xu, Q., Sun, J., Yin, Y., and Yu, G. (2017). Facile synthesis of blocky $\mathrm{SiO}_{\mathrm{x}} / \mathrm{C}$ with graphite-like structure for high-performance lithium-ion battery anodes. $A d v$. Funct. Mater.28:1705235. doi: 10.1002/adfm.201705235

Xu, Q., Sun, J., Yu, Z., Yin, Y., Xin, S., Yu, S., et al. (2018). $\mathrm{SiO}_{\mathrm{x}}$ encapsulated in graphene bubble film: an ultrastable Li-on battery anode. Adv. Mater. 30:1707430. doi: 10.1002/adma.201707430

Yang, S., Wang, P., Wei, H., Tang, L., Zhang, X., He, Z., et al. (2019). $\quad \mathrm{Li}_{4} \mathrm{~V}_{2} \mathrm{Mn}\left(\mathrm{PO}_{4}\right)_{4}$-stablized $\mathrm{Li}\left[\mathrm{Li}_{0.2} \mathrm{Mn}_{0.54} \mathrm{Ni}_{0.13} \mathrm{Co}_{0.13}\right] \mathrm{O}_{2}$ cathode materials for lithium ion batteries. Nano Energy 63:103889. doi: 10.1016/j.nanoen.2019.103889

Yi, T., Peng, P., Fang, Z., Zhu, Y., Xie, Y., and Luo, S. (2019). Carboncoated $\mathrm{LiMn}_{1-\mathrm{x}} \mathrm{Fe}_{\mathrm{x}} \mathrm{PO}_{4}(0 \leq \mathrm{x} \leq 0.5)$ nanocomposites as high-performance cathode materials for Li-ion battery. Compos. Part B. 175:107067. doi: 10.1016/j.compositesb.2019.107067

Yi, T., Zhu, Y., Tao, W., Luo, S., Xie, Y., and Li, X. (2018). Recent advances in the research of $\mathrm{MLi}_{2} \mathrm{Ti}_{6} \mathrm{O}_{14}(\mathrm{M}=2 \mathrm{Na}, \mathrm{Sr}, \mathrm{Ba}, \mathrm{Pb})$ anode materials for $\mathrm{Li}$-ion batteries. J. Power Sour. 339, 26-41. doi: 10.1016/j.jpowsour.2018.07.086

Yu, B., Hwa, Y., Park, C., and Sohn, H. (2013). Reaction mechanism and enhancement of cyclability of $\mathrm{SiO}$ anodes by surface etching with $\mathrm{NaOH}$ for Li-ion batteries. J. Mater. Chem. A. 1:4820. doi: 10.1039/c3ta00045a

Yu, Q., Ge, P., Liu, Z., Xu, M., Yang, W., Zhou, L., et al. (2018). Ultrafine $\mathrm{SiO}_{\mathrm{x}} / \mathrm{C}$ nanospheres and their pomegranate-like assemblies for high performance lithium storage. J. Mater. Chem. A 10:1039. doi: 10.1039/C8TA03987A

Zhao, L., Dvorak, D., and Obrovac, M. (2016). Layered amorphous silicon as negative electrodes in lithium-ion batteries. J. Power Sour. 332, 290-298. doi: 10.1016/j.jpowsour.2016.09.124

Zheng, J., Yang, Z., He, Z., Tong, H., Yu, W., and Zhang, J. (2018). In situ formed $\mathrm{LiNi}_{0.8} \mathrm{Co}_{0.15} \mathrm{Al}_{0.05} \mathrm{O}_{2} @ \mathrm{Li}_{4} \mathrm{SiO}_{4}$ composite cathode material with high rate capability and long cycling stability for lithium-ion batteries. Nano Energy 53, 613-621. doi: 10.1016/j.nanoen.2018.09.014

Zheng, S., Dou, A., Su, M., and Liu, Y. (2020). Influence of Nb doping on electrochemical performance of nanostructured cation disordered 
$\mathrm{Li}_{1+\mathrm{x} / 100} \mathrm{Ni}_{1 / 2-\mathrm{x} / 100} \mathrm{Ti}_{1 / 2-\mathrm{x} / 100} \mathrm{Nb}_{\mathrm{x} / 100} \mathrm{O}_{2}$ composites cathode for $\mathrm{Li}$-ion batteries. J. Nanosci. Nanotechnol. 20, 452-459. doi: 10.1166/jnn.2020.16884

Zheng, S., Liu, D., Tao, L., Fan, X., Liu, K., Liang, G., et al. (2019). Electrochemistry and redox characterization of rock-salttype lithium metal oxides $\mathrm{Li}_{1+z / 3} \mathrm{Ni}_{1 / 2-z / 2} \mathrm{Ti}_{1 / 2+z / 6} \mathrm{O}_{2}$ for $\mathrm{Li}$-ion batteries. Alloys J. Compd. 773, 1-10. doi: 10.1016/j.jallcom.2018. 09.261

Zhou, C., Wang, P., Zhang, B., Tang, L., and Tong, H., He, Z., et al. (2019). Formation and effect of residual lithium compounds on Li-rich cathode material $\mathrm{Li}_{1.35}\left[\mathrm{Ni}_{0.35} \mathrm{Mn}_{0.65}\right] \mathrm{O}_{2}$. ACS Appl. Mater. Interfaces 11, 11518-11523. doi: 10.1021 /acsami.9b01806

Zhu, L., Du, F., Zhuang, Y., Dai, H., Cao, H., Adkins, J., et al. (2019). Effect of crosslinking binders on Li-storage behavior of silicon particles as anodes for lithium ion batteries. J. Electroanal. Chem. 845, 22-30. doi: 10.1016/j.jelechem.2019.05.019

Zuo, D., Song, S., An, C., Tang, L., He, Z., and Zheng, J. (2019). Synthesis of sandwich-likestructured $\mathrm{Sn} / \mathrm{SnO}_{\mathrm{x}} @ \mathrm{MXene}$ composite through in-situ growth for highly reversible lithium storage. Nano Energy 62, 401-409. doi: 10.1016/j.nanoen.2019.05.062

Zuo, X., Zhu, J., Müller-Buschbaum, P., and Cheng, Y. (2017). Silicon based lithium-ion battery anodes: a chronicle perspective review. Nano Energy 31, 113-143. doi: 10.1016/j.nanoen.2016.11.013

Conflict of Interest: The authors declare that the research was conducted in the absence of any commercial or financial relationships that could be construed as a potential conflict of interest.

Copyright (c) 2020 Liao, Liang, Ren and Huang. This is an open-access article distributed under the terms of the Creative Commons Attribution License (CC BY). The use, distribution or reproduction in other forums is permitted, provided the original author(s) and the copyright owner(s) are credited and that the original publication in this journal is cited, in accordance with accepted academic practice. No use, distribution or reproduction is permitted which does not comply with these terms. 